\title{
The difference of Lactobacillus vaginalis normal flora bacteria on vaginal swab on women at childbearing age using Piper betle L., soap, and water as vaginal cleanser
}

\author{
Mudayatiningsih Sri ${ }^{*}$ and Suryandari Endang Sri Dewi Hastuti \\ Malang State Health Polytechnic, Malang, Indonesia. \\ Publication history: Received on 21 November 2018; revised on 10 December 2018; accepted on 15 December 2018
}

Article DOI: https://doi.org/10.30574/gscbps.2018.5.3.0143

\begin{abstract}
Hygiene and body care in women including genitalia's organ holds a very vital role due to changes in pH balance, germs infection, physical factors, and the issue of self hygiene. Soap and Piper betle L. are types of genitalia cleanser which is often used by women. Piper betle L. contains phenol and tannin which can be used to treat female organs. Phenol is proven to be able to kill bacteria effectively including killing Candida albicans and Lactobacillus flora. Soaps containing triclosan which can damage certain enzyme synthesis in a cell can kill the pathogen bacterial bacteria even also the normal flora. Normal flora that resides in the female organs function to protect the area against fungal infection and other microorganism's invasion of mucosal tissues of the vagina. Lactobacillus vaginalis is one of the normal vaginal flora with almost $95 \%$ of the normal vaginal flora, which produces lactic acid mixed with vaginal secretions resulting in acidic conditions in the vaginal area with a pH of 3.8-4.2. The purpose of this research was to prove that there is a difference in the number of normal bacteria Lactobacillus vaginalis on vaginal swab in women at childbearing age who use Piper betle L., soap and water as cleansers. This study is a descriptive comparative research with posttest only design. The analysis used t- test with a 95\% confidence interval conducted on 30 respondents who were divided into three groups. The results showed that women at childbearing age who used Piper betle L. and soaps as vaginal cleanser experienced changes in their vaginal $\mathrm{pH}$, so it was proven statistically that it can significantly decrease the number of Lactobacillus vaginalis.
\end{abstract}

Keywords: Cleanser; Lactobacillus vaginalis; Piper betle L.; Water

\section{Introduction}

Now a days, hygiene and personal care are getting more important since the environment has become more deteriorated which make us more aware about our body's health. Air pollution, sun rays, and anomaly of the season influence the health of the body, including the growth and development of viruses and fungi in the body. Hygiene and personal care for women, including their intimate organs play a very vital role, because of the differences in body structure of women and men. Feminine area care is very important because it is closely related to the circulation of menstruation, fluor albus, pregnancy and sexual intercourse which can disturb the pH balance of the genital area. Changes in $\mathrm{pH}$ balance can be caused by the spread of bacterial infection, physical factors, issues of personal hygiene and the use of cleanser agents or soap for feminine area. Betel soap is made from betel leaf that contains phenols and tannins [1] that can be used to treat women's organ. Tannin substances can reduce the natural vaginal discharge or excessive discharge (flour albus), while phenol has killing power on bacteria. This makes many women often use this betel soap to clean the feminine area without considering the impact.

Female sexual organs are the most sensitive organ in female body, this organ has the ability to clear the area itself with normal flora. Normal flora that resides in the female organs function to protect the area against fungal infection and

\footnotetext{
${ }^{*}$ Corresponding author

E-mail address: mudayati69@gmail.com
} 
other microorganism's invasion of mucosal tissues of the vagina [2]. Lactobacillus vaginalis is one of the normal vaginal flora with almost 95 percent of the normal vaginal flora, which produces lactic acid [3] mixed with vaginal secretions resulting in acidic conditions in the vaginal area with a $\mathrm{pH}$ of 3.8-4.2. The vaginal $\mathrm{pH}$ acidic conditions serve to prevent the growth of Candida albicans as pathogen bacteria. Normally, clean water is sufficient to clean the feminine area, but in reality, there are now many women use cleanser materials such as betel soap (Piper betle L.) or any kind of soap to maintain the cleanliness and to reduce fluor albus. Betel soap contains antiseptic that can kill normal flora while other kinds of soap has an alkaline $\mathrm{pH}$ content which causes vaginal $\mathrm{pH}$ becomes alkaline. As a result, the normal flora of the vagina is disrupted and pathogenic fungi and some bacteria are growing well. The amount of normal vaginal flora in a healthy woman is between 50-75 percent which can suppress other bacteria growth [4]. The purpose of this research was to prove that there is a difference in the number of normal bacteria Lactobacillus vaginalis on vaginal swab in women at childbearing age who use Piper betle L., soap and water as cleansers.

\section{Material and methods}

\subsection{Research design}

This study was conducted on women at childbearing age who use the vaginal cleanser of Piper betle L., soap, and water with the number of respondents in each group was 10 respondents who were in the area of cluster 1 and 2 at Gondanglegi Wetan District, Malang. The sample was selected from the population by using purposive sampling technique and met the inclusion criteria, namely: has been married, aged between 20-45 years, using vaginal cleanser with Piper betle L., soap and water, was not on menstruating period, and willing to become respondents. To evaluate the number of Lactobacillus bacteria, the researchers used vaginal swabs with gram staining [5]. Vaginal swab specimen collection process was using standard operating procedures [6] and further tested in microbiology laboratory.

\subsection{Treatment}

Betel soap used was with $\mathrm{pH}$ value of \pm 4.5 , which was used approximately one month prior to data collection. Soap is a solid bathing soap with $\mathrm{pH}$ of $\pm 8-10$, which was used approximately one month prior to data collection. The water was coming from the well or tap water used for daily cleanser. Data collection was further analyzed using T-test analysis with significance level of $0.05[7,8]$. This test was to determine the difference in the number of Lactobacillus vaginalis on vaginal swab in women of childbearing age, among those who used Piper betle L. cleanser, soap, and water.

\subsection{Ethical clearance}

This study has fulfilled the requirement of ethical committee of experimental research from the Ethic Committee of Polytechnic of Health, The Ministry of Health in Malang, Indonesia number 061/KEPK-POLKESMA/2013.

\section{Results and discussion}

Table 1 Normal vaginal flora respondents per field of view based on age characteristics

\begin{tabular}{|c|c|c|c|c|c|c|c|}
\hline \multirow{3}{*}{ Sr. No } & \multirow{3}{*}{$\begin{array}{c}\text { Age } \\
\text { characteristic } \\
\text { (year) }\end{array}$} & \multicolumn{6}{|c|}{ Vagina cleanser } \\
\hline & & \multicolumn{2}{|c|}{ Piper betle Linn } & \multicolumn{2}{|r|}{ Soap } & \multicolumn{2}{|r|}{ Water } \\
\hline & & $\mathbf{F}$ & $\begin{array}{c}\text { Lactobacillus sp. } \\
\text { (\%) }\end{array}$ & $\mathbf{F}$ & $\begin{array}{l}\text { Lactobacillus sp. } \\
\text { (\%) }\end{array}$ & $\mathbf{F}$ & $\begin{array}{c}\text { Lactobacillus sp. } \\
(\%)\end{array}$ \\
\hline 1. & $20-25$ & 1 & 40.2 & 1 & 50.6 & 0 & 0.0 \\
\hline 2. & $26-30$ & 2 & 34.1 & 1 & 37.0 & 0 & 0.0 \\
\hline 3. & $31-35$ & 5 & 17.2 & 6 & 20.0 & 1 & 67.8 \\
\hline 4. & $36-40$ & 1 & 25.1 & 2 & 25.0 & 4 & 58.1 \\
\hline 5. & $41-45$ & 1 & 10.2 & 0 & 0.0 & 5 & 52.3 \\
\hline \multicolumn{2}{|c|}{ Total respondents } & 10 & & 10 & & 10 & \\
\hline \multicolumn{2}{|c|}{$\begin{array}{c}\text { Average of Lactobacillus } \\
\text { sp. } \%\end{array}$} & & 22.97 & & 24.19 & & 56.17 \\
\hline
\end{tabular}

Description: F: Frequency 
The demographic characteristics of the distribution of the data showed that $40 \%$ of respondents were at the age of 31 35 years, most of them were married (76.67\%), 50\% of respondents was junior high graduates and most of them were housewives (56.67\%). Medical history data showed as much as 56.7\% of respondents with parity of 1-2, mostly complain with fluor albus (50\%), the majority of respondents did not suffer from diabetes (83.3\%), mostly used contraceptive pills (63.3\%) and many of them use pantyliner (46.7\%). The examination of vaginal acidity was using dip stick (merck branded) with pH range of 3-10, showed more than half of respondents (16 people) had vaginal acidity with $\mathrm{pH} \leq 5$ and at the largest were at the age of 31-35 years with 7 people (43.7\%). While those who had pH $\geq 5$ were mostly at the age group of 36-40 years old with 6 people (42.8\%). Vaginal pH becomes alkaline (pH $\geq 5)$ on 4 of 10 respondents who used soap, 6 out of 10 respondents who used Piper betle L. and 2 of 10 respondents who used water for cleanser the vagina. The average percentage amount of the normal vaginal flora (bacteria Lactobacillus sp) per field of view at the lowest was in the group of respondents who used Piper betle L. as vaginal cleanser (22.97\%). The respondents who used water still showed average percentage of the number of bacteria per field of view at high level $(56.17 \%)$. It showed that the use of vagina Piper betle L. cleansers can reduce the number of normal vaginal flora (Table 1).

Table 2 Reproductive tract complaints based on the use of vaginal cleanser

\begin{tabular}{|c|c|c|c|c|c|c|c|}
\hline \multirow{3}{*}{$\begin{array}{l}\text { Sr. } \\
\text { No. }\end{array}$} & \multirow{3}{*}{$\begin{array}{c}\text { Reproductive } \\
\text { tract } \\
\text { complaints }\end{array}$} & \multicolumn{6}{|c|}{ Vagina cleanser } \\
\hline & & \multicolumn{2}{|c|}{ Piper betle Linn } & \multicolumn{2}{|r|}{ Soap } & \multicolumn{2}{|c|}{ Water } \\
\hline & & f & $\begin{array}{c}\text { Percentage } \\
(\%)\end{array}$ & $\mathbf{f}$ & $\begin{array}{c}\text { Percentage } \\
(\%)\end{array}$ & f & $\begin{array}{c}\text { Percentage } \\
(\%)\end{array}$ \\
\hline 1 & Fluor albus & 8 & 80.0 & 6 & 60.0 & 1 & 10.0 \\
\hline 2 & Itchiness & 0 & 0.0 & 2 & 20.0 & 0.0 & 0.0 \\
\hline 3 & Fluor albus and itchiness & 1 & 10.0 & 0 & 0.0 & 0.0 & 0.0 \\
\hline \multirow[t]{2}{*}{4} & No complaints & 1 & 10.0 & 2 & 20.0 & 9 & 90.0 \\
\hline & Total & 10 & 100 & 10 & 100 & 10 & 100 \\
\hline
\end{tabular}

Description: F: Frequency

Complaints of the reproductive tract mostly found in the group of respondents who use Piper betle L. vaginal cleanser was fluor albus with 8 subjects (80\%), while on the group using water as vaginal cleanser, there was only 1 person $(10 \%)$ who had fluor albus (Table 2). The results of the three groups of respondents were compared using independence T-test with the requirement that the data was on normal distribution. Normality test using Kolmogorov-Smirnov normality test was used to get data in normal distribution. The test results showed that the number of Lactobacillus vaginalis bacteria at the use of Piper betle L., soap, and water as cleanser agent was in normal distribution with $\mathrm{p}>0.05$.

Table 3 The result of T-test independence on the difference of vaginal normal flora of the respondents

\begin{tabular}{clccc}
\hline Sr. No. & $\begin{array}{c}\text { Vagina } \\
\text { cleanser }\end{array}$ & $\begin{array}{c}\text { The average number } \\
\text { of vaginal normal } \\
\text { flora }\end{array}$ & p-value & Results \\
\hline \multirow{2}{*}{ 1. } & Piper betle L. & 22.970 & 0.80 & $\begin{array}{c}\text { Not significantly } \\
\text { different }\end{array}$ \\
& Soap & 24.190 & 0.00 & $\begin{array}{c}\text { Significantly } \\
\text { different }\end{array}$ \\
\hline 2. & Piper betle L. & 22.970 & & Significantly \\
& Water & 56.170 & 0.00 & different \\
\hline
\end{tabular}

The results of this study indicated that the use of Piper betle L. as vagina cleanser in women of childbearing age caused a significant difference to the amount of the normal flora of Lactobacillus vaginalis as compared with the use of water as vaginal cleanser. Statistical analysis using independent T-test obtained p value $=0.00(<0.005)$, meaning that there 
was a very significant difference between the use of Piper betle L. and water, so that it can be concluded that the use of Piper betle L. can lower the amount of normal flora of Lactobacillus vaginalis (Table 3).

A decrease in the normal flora of Lactobacillus vaginalis may be attributable to the change of vaginal $\mathrm{pH}$ to become alkaline. Besides, the use of substances excessive vaginal cleanser will kill the normal flora, so that it will be easy for pathogenic bacteria to enter vagina. Besides, betel leaves contain phenols that have a mechanism of phenolic action by destroying plasma membrane, inactivating the enzyme, and protein denaturation to kill bacteria. The amount of normal flora of Lactobacillus vaginalis in the group taking Piper betle L. as vaginal cleanser was less compared to other groups. The use of soap betel excessively will kill the normal flora resulting in a decrease in the acidity of the vagina so that pathogenic bacteria and fungi can grow well, so that Lactobacillus bacteria will be lost against pathogen bacteria [4].

The use of soap as vaginal cleanser in women of childbearing age caused a significant difference to the amount of normal flora of Lactobacillus vaginalis as compared with the use of vaginal cleanser using water. The results of statistical analysis using independent T-test obtained $p$ value $=0.00(<0.005)$, meaning that there was a very significant difference between the users of soap and water, so it can be concluded that the users of soap can reduce the amount of normal flora of Lactobacillus vaginalis (Table 3).

A decrease in the normal flora of Lactobacillus vaginalis because of the soap was because soap is alkaline or containing carbonate ions with a pH of 8.4, while the normal vaginal $\mathrm{pH}$ is between 3.8 to 4.2 . The use of soap as cleanser can cause changes in the acidity of the vagina that causes disturbance in the growth of normal flora. Meanwhile, the disturbance of the normal flora will cause imbalance on the vaginal area and causes the skin to become dry and itchy. Besides, the content of the antibacterial triclosan soap that can damage the synthesis of certain enzymes in cells, can kill the normal flora bacteria and even pathogenic bacteria, thus allowing other occurrence resulting in bacterial colonies can grow more dominantly in female organs. Research conducted by Brown [9] on 141 women about the use of soap for cleansing the vaginal area got the data that 66 percent of women experiencing bacterial and fungal infections and 44 percent suffered from candidiasis. The natural balance in the vagina can be disrupted by the presence of some soaps, shower gels, perfumes, and can cause irritation to sensitive skin and the risk of fungal and bacterial infections. Vaginal cleanser using water in women of childbearing age caused a significant difference to the amount of the normal flora of Lactobacillus vaginalis. The results of statistical analysis using independent T-test showed that $\mathrm{p}$ value $=0.00(<0.005)$, meaning that there was a very significant difference between the use of water, soap, and Piper betle Linn, so it can be concluded that the use of water can reduce less amount of Lactobacillus vaginalis normal flora compared to the other cleanser agents (Table 3).

The group of respondents who use water had a normal vaginal flora in greater amounts when compared to the other groups. The use of water as vaginal cleanser only affecting a little amount of Lactobacillus vaginalis normal bacteria, so as to prevent the growth of bad bacteria around female organs area. A decrease in the normal flora of Lactobacillus vaginalis on women who used water as cleanser agent can result from several factors such as contraceptive use and age. Contraception can increase the likelihood of vaginal excessive mucus production, causing the increase of humidity around vaginal area. Increasing humidity causes better growth for pathogenic bacteria and fungi that can indirectly lower the normal flora of Lactobacillus vaginalis. Women who are going to get menopause period also experience reducing production of estrogen. Estrogen plays a role in the synthesis of glycogen needed by Lactobacillus vaginalis to metabolize nutrients and produce lactic acid which makes the vaginal $\mathrm{pH}$ becomes acidic, so that with the decreasing levels of estrogen will result in decreasing amount of Lactobacillus vaginalis, which means also causes the disappearance of the acid environment in the vagina. The results of research conducted by Gustafsson et al., [10] showed that the number of Lactobacillus crispatus vaginal flora was lower in postmenopausal women compared to women at childbearing age, with $\mathrm{p}=0.036$. The results of other studies on the levels of glycogen in the vagina conducted by Mirmonsef et al., [11] showed that glycogen plays a role in the growth of colonies of Lactobacillus in the vaginal area. The decrease in the number of normal flora on the use of vagina cleansers with Piper betle Linn compared to the use of soap showed no significant difference, in accordance with the test results obtained by independent t-test $p$ value $=0802$ $(>\alpha=0.05)$, meaning that the two types of cleansers is similarly meaningful, because both have similar effect in reducing Lactobacillus vaginalis.

\section{Conclusion}

The use of Piper betle L. and soap for vagina cleanser on women at childbearing age has bigger impact on the changes of vaginal $\mathrm{pH}$ and it can decrease the level of Lactobacillus vaginalis, compared to the use of water as vaginal cleanser. It is recommended that for further research the number of samples needs to be increased and the research is not only conducted on childbearing age group and more research can be conducted to find out the correlation between the decrease of Lactobacillus vaginalis with infection in teenagers, young women and pre menapouse women. 


\section{Compliance with ethical standards}

\section{Acknowledgments}

The authors will like to thank the chairman of Badan Penerbitan Jurnal (BPJ) Faculty of Medicine, Universitas Brawijaya, Dr. Husnul Khotimah, S.Si, M.Kes, for the assistance to publish this resesarch articles.

\section{Disclosure of conflict of interest}

The authors declare that there is no conflict of interest

\section{Statement of ethical approval}

This study has fulfilled the requirement of ethical committee of experimental research from the Ethic Committee of Polytechnic of Health, The Ministry of Health in Malang, Indonesia number 061/KEPK-POLKESMA/2013.

\section{Statement of informed consent}

Informed consent was obtained from all individual participants included in the study.

\section{References}

[1] Rathee JS, Patro BS, Mula S, Gamre S and Chattopadhyay S. (2006). Antioxidant activity of Piper betel leaf extract and its constituents. Journal of agricultural and food chemistry, 54(24), 9046-9054.

[2] Brooks GF, Butel JS and Morse SA. (2006). Medical microbiology. United States, 25 ${ }^{\text {th }}$.

[3] Boskey ER, Cone RA, Whaley KJ and Moench TR. (2001). Origins of vaginal acidity: high D/L lactate ratio is consistent with bacteria being the primary source. Human Reproduction, 16(9), 1809-1813.

[4] Wesley AV and Margaret FW. (1993). Basics of Microbiology. Erlangga, Jakarta.

[5] Nugent RP, Krohn MA and Hillier SL. (1991). (1991). Reliability of diagnosing bacterial vaginosis is improved by a standardized method of gram stain interpretation. Journal of clinical microbiology, 29(2), 297-301.

[6] Sugiyono. (2008). Methodology of Quantitative and Qualitative and R\&D Research. Penerbit Alfabeta. Bandung

[7] Dahlan MS. (2009). Statistics for Health and Medical. Jakarta Salemba Medika.

[8] Budiarto E. (2003). Methodology of medical research, an introduction. Penerbit Buku Kedokteran EGC. Jakarta

[9] Brown JM, Poirot E, Hess KL, Brown S, Vertucci M and Hezareh M. (2016). Motivations for intravaginal product use among a cohort of women in Los Angeles. PLoS ONE, 11(3), e0151378.

[10] Gustafsson RJ, Ahrné S, Jeppsson B, Benoni C, Olsson C, Stjernquist M and Ohlsson B. (2011). The Lactobacillus flora in vagina and rectum of fertile and postmenopausal healthy Swedish women. BMC women's health, 11(1), 17.

[11] Mirmonsef P, Hotton AL, Gilbert D, Burgad D, Landay A, Weber KM, Cohen M, Ravel J and Spear GT. (2014). Free glycogen in vaginal fluids is associated with Lactobacillus colonization and low vaginal pH. PLoS One, 9(7), e102467.

\section{How to cite this article}

Mudayatiningsih S and Suryandari ESDH. (2018). The difference of Lactobacillus vaginalis normal flora bacteria on vaginal swab on women at childbearing age using Piper betle L., soap, and water as vaginal cleanser. GSC Biological and Pharmaceutical Sciences, 5(3), 66-70. 